\title{
India and United States quarrel over intellectual property rights
}

\section{New Delhi \& Washington}

Neither India nor the United States seems likely to compromise in a worsening quarrel over the protection of intellectual property rights. Many joint research projects launched under the recently renewed joint Science and Technology Initiative are now at risk.

US negotiators claim that the Indian patent system does not protect inventions that may arise in joint research. But India, which is not (and does not wish to be) a party to the Paris Convention, maintains that inventions can be protected adequately under the prevailing laws in each country.

In April 1987, President Reagan ordered US agencies to sign science agreements only with countries that protect US intellectual property rights. "Since then we had been under tremendous pressure from the United States to change our patent law but we did not buckle", a spokesman of the Indian Department of Science and Technology (DST) said.

Because of the quarrel, William Graham. Reagan's science adviser, twice postponed a visit to India to renew the Science and Technology Initiative. The agreement was eventually signed on 5 October, but only after a personal letter was sent from Prime Minister Rajiv Gandhi to President Reagan, and a decision made to resolve remaining differences through bilateral discussions. A US negotiating team will visit India later this month.

Indian patent protection concentrates on the process of production, rather than the product, enabling Indian companies to manufacture any item provided they are able to create a new production process. Product patents are granted only in selected fields for periods of 7 to 14 years. Atomic energy and living organisms cannot be patented at all.

The United States is asking for changes that will grant 20 -year product patents in all fields to prevent what it calls "thievery of intellectual property". But the Indian government claims that its system has helped the country produce cheap drugs and agrochemicals and fears that changes would hamper industrialization, boost drug prices and shut off foreign markets.

Graham warns that the Indian patent regime is an impediment to transfer of high technologies and will harm the Science and Technology Initiative. If joint research "is to move from basic science to the marketplace", India's system must be aligned with that of the United States, he says. The controversy also threatens progress on the Vaccine Action Programme under which Indian and US scientists will jointly develop and test genetically engineered vaccines (the vaccination programme faces other hazards, see Nature 335, 584)

In India, opposition to change is strong. Gandhi's science advisory council has cautioned that "nothing should be done to undermine the supremancy of the Indian patents act". And industry has formed a national working group to counter US pressure.

In Washington, trade officials are eager to force India to compromise. In late October they were successful in imposing import tariffs on Brazil as a punishment for that country's unwillingness to grant patent protection to US pharmaceutical and chemical products. But the US State Department opposes such tough action with India, given its strategic importance and the links it has forged with the Soviet Union. A more likely outcome is that the United States will threaten to back out of some joint high-technology projects.

K.S. Jayaraman \& Alun Anderson

\section{IRL Press becomes an OUP acquisition} London

A FIGHr for a highly successful publisher of textbooks and journals in the biomedical sciences has ended with the University of Oxford emerging as the winner. The university's publishing company, Oxford University Press (OUP), has taken over IRL Press, well known as the publisher of the journals Nucleic Acids Research and the $E M B O$ Journal. The price paid has not been disclosed.

IRL plans to build on its success, using the wider marketing network of OUP to increase the circulation of its journals. The company plans to move out of its narrow subject range and to publish more textbooks; it will retain its name.

OUP, which is more than 500 years old, plans to expand into journals and textbooks from its main role as a publisher of scholarly works such as theses, and to specialize in certain areas. The main aim of OUP is charitable and profits from IRL will help to support less profitable sectors. OUP has no overall profits; it exists entirely on cash flow and reserves, and is exempt from corporate tax.

The take-over has been "relatively painless", says John Bradley of IRL. The company was in a strong position to ensure favourable terms for its staff and those currently working on the journals of OUP will move to the premises of IRL, near Oxford. Christine McGourty
Student Chinese overstaying in United States

\section{Washington}

STudents and researchers from the People's Republic of China are flocking to US universities in unparalleled numbers but many are putting off their return home. This pattern is causing considerable concern in China that the best and brightest students may be lost to the United States, and not a little anxiety in the United States that engineering schools are too dependent on Chinese researchers.

A report* from the National Academy of Sciences released last week estimates that there are 29,000 students and researchers from the People's Republic in US universities. The majority are in engineering and science faculties; statistics from the National Academy of Sciences show that more engineering doctorates are granted to students from China than to the students of any other two foreign nations combined. With close to 50 per cent of engineering doctorates now going to non-US citizens, that gives the Chinese a formidable presence.

Many Chinese researchers and students are now adopting a "wait-and-see attitude", according to the report, attempting to postpone their return while watching political developments in China. Recent student demonstrations in China and the dismissal of outspoken academics, such as Fang Lizhi of the University of Science and Technology in Heifei, "visibly alarmed" the student community abroad.

But political worries are not the whole story. Between 1978 and late 1986 almost all of the 19,500 officially sponsored students and researchers who had completed their courses went home. But Chinese students are now much more at home in the United States, and much more knowledgeable about US immigration law. The shift from Mao's slogan of "serve the people" to today's "it is all right to be rich" means, the report says, that there is a "mood of selfishness" that leaves out a sense of obligation to return home.

But the report sees nothing alarming in these trends. Although Beijing is enacting new measures to try to make sure foreign students return (and trying to increase the tiny number of students going to Europe where visa regulations are much stricter), the brain drain is likely to reverse naturally as China continues on the road to modernization. The pace of modernization may even be speeded up by foreign students who refuse to return home if proper use is not made of their skills.

Alun Anderson

* Chinese Students in America: Policies, Issues and Numbers National Academy Press. Washington, DC, 1988 